\title{
Consultative Jurisdiction of Supreme Court of India: Assessment and Critical Analysis
}

\author{
Dr. Dharmendra Kumar Singh ${ }^{1}$, Dr. Amit Singh ${ }^{2}$ \\ ${ }^{1-}$ Associate Professor, Department of Law, Bareilly College, Bareilly (India) \\ ${ }^{2-}$ Assistant Professor, Department of Law, MJP Rohilkhand University, Bareilly (India) \\ Corresponding Author E-mail:dksingh@bareillycollege.org(DKS)
}

\begin{abstract}
This research paper deals with the analysis of Article 143 of Consultative Jurisdiction and its nature and scope. An effort has been made to present the advantages of Consultative Jurisdiction of Supreme Court of India. The main attribute of this research paper is that some suggestive measures have been given for the cautious use of Consultative Jurisdiction. This paper also points out the criticism of Consultative Jurisdiction of Supreme Court of India and assesses the criticism with a radical approach.
\end{abstract}

Keywords: Consultative Jurisdiction, Article 143, Supreme Court, Constitution of India, President

\section{INTRODUCTION}

The institution of a consultative jurisdiction established a channel between the Executive and the judiciary. This naturally raises doubts about the Executive - judiciary collaboration. As the judges are traditionally known for adjudicating on disputes, there being counsel of the President is of great constitutional significance. Executive seeking advice from judiciary makes unique relationship between the two organs of Government in a Parliamentary System.

Theoretically, a Court of Law should not have consultative jurisdiction because the Court while giving an advice, exercises no judicial function. Lord Coke in the seventeenth century refused to give an opinion to King James I, and the American Supreme Court gave a similar answer to the President Washington in 1795, when the latter asked it to advice on certain questions arising under certain treaties. A court of law should decide issues arising out in cases and controversies duly litigated before it [1]. A friendly and hypothetical question set for opinion must be normally outside the pale of judicial function of the court.

In spite of the theoretical objections, the advisory jurisdiction is often found necessary. The expediency of this has been recognized by Article 143 udner which the President can ask the Supreme Court to give its opinion in respect of a question of public importance. As the judges are traditionally known for adjudicating on disputes, there being counsel of the President is of great constitutional significance. Executive seeking advice from judiciary makes unique relationship between the two organs of Government in Parliamentary System. It assumes greater significance in a federal structure where state units have nothing to do with the provisions under Article 143[2].

Article 124 of the Constitution of India established the Supreme Court of India as the pinnacle of the Indian Judiciary. The Constitution has conferred various jurisdictions on the Supreme Court. They are enumerated as follows:-

i. Writ jurisdiction under article $\mathbf{3 2}$ for the enforcement of the fundamental rights.

ii. Original jurisdiction under article 131.

iii. Appellate jurisdiction under articles 132, 133 \& 134.

iv. Jurisdiction to grant special leave to appeal under article $\mathbf{1 3 6}$.

v. Jurisdiction under article $\mathbf{1 3 7}$ to review any judgment pronounced by it or order made by it.

vi. Advisory jurisdiction under article 143.

vii. Jurisdiction under article 317 (1) to hold enquiry and to report to the President for the removal of the chairman or the members of public service commissions.

viii. Jurisdiction under article $\mathbf{7 1}$ for matters relating to, or connected with the election of a President or vice President.

According to Art. 143 (1), when it appears to the President that a question of law or fact has arisen, or is likely to arise, which is of such a nature and of such public importance, that it is 'expedient' to obtain the opinion of the Supreme Court upon it, he may prefer it to the Court for consideration. The Court then may, after such hearing as it thinks fit, report to the President its opinion thereon. Under Art.143 (2), a matter which is 
excluded from the Supreme Court's jurisdiction under Art.131 may be referred to it for opinion and the Court shall, after such hearing as it thinks fit, report to the President its opinion thereon.

A report under the above provision is to be made by the Court in accordance with an opinion delivered in open court [Art. 145 (4)] with the concurrence of the majority of Judges [Art. 145 (5)]. A Judge who does not concur has liberty to deliver a dissenting opinion [Art. 145 (4)]. The reference is to be heard by a Bench of not less than five Judges [Art. 145 (3)]. Thus, the procedure in respect of the exercise of the advisory jurisdiction has, as far as possible, been approximated to a judicial hearing. The objective of this Research work is to point out the advantages and criticism of Consultative Jurisdiction. It also puts forth the assessment of the criticism and provides vital suggestions in the further development of Consultative Jurisdiction with a reference to the position of states as its priority.

\section{NATURE AND SCOPE OF CONSULTATIVE JURISDICTION}

The nature of Art. 143 (1) is quite broad. There is no condition that the President can refer only such questions as pertain to his powers, functions and duties or those of the Central Government. The President can seek the opinion of the Supreme Court on any question of law or fact which appears to him to be of such a nature and of such public importance that it is expedient to obtain the Court's opinion. It is not necessary that only a question which has actually arisen may be referred to the Court for its opinion. The President may make a reference even at an anterior stage, namely, when the question is likely to arise in future. It is a matter essentially for the President to decide whether the question is of such a nature and of such public importance that it is expedient to seek the Court's opinion thereon.

The President is entitled to refer to the Supreme Court for its opinion any question of law or fact whether or not it has any relation to the entries in Lists I and III, or whether it falls in the Central sphere or in the State sphere. What Art. 143 (1) requires is the President's satisfaction - (i) a question of law or fact has arisen or it likely to arise, and (ii) the question is of such a nature and of such public importance that it is expedient to obtain 'the Court's opinion on it. The satisfaction of the President on both these counts would justify reference to the Supreme Court. Questions regarding the validity of a statute in force or a proposed Bill may be referred to the Court as Art. 143 (1) contemplates reference of a question of law which is "likely to arise'. The phraseology of the constitutional provision is quite broad to cover all types of references. The Court has stated that it is "well within its jurisdiction to answer / advise the President in a reference made under Art. 143 (1) of the Constitution of India if the questions referred are likely to arise in future or such questions are of public importance or there is no decision of this Court which has already decided the question referred"[3].

The Court has now clarified that it cannot be asked, under Art.143 (1) to reconsider any of its earlier decisions. The President can refer only such legal question as has not been decided by the Court earlier. The Court has reasoned that when in its ad judicatory jurisdiction, it has pronounced an authoritative opinion on a question of law, there neither remains any doubt about the question of law nor does it remain res Integra so as to require the President to know what the true position of law on the question is. The Court can review its earlier decision only under Art. 137.

The Supreme Court has rejected the contention that under Art. 143, the President can ask the Court to reconsider any of its previous decisions. The Court has observed that under the Constitution, the Court enjoys no appellate jurisdiction over itself. The Court cannot convert its advisory jurisdiction into an appellate one. "Nor is it competent for the President to invest us with an appellate jurisdiction over the said decision through a reference under Article 143 of the Constitution". To interpret Art.143 (1) as conferring on the executive power to ask the Supreme Court to revise its own decision, would cause a serious inroad into the independence of the judiciary [4]. In Art. 143 (1), the use of the word 'may' indicates that the Supreme Court is not obligated to express its opinion on the reference made to it. It has discretion in the matter and may, in a proper case, for good reasons, decline to express any opinion on the question submitted to it. Such a situation may perhaps arise if purely socio-economic or political questions having no constitutional significance are referred to the Court, or a reference raises hypothetical issues which it may not be possible to answer without a full setting of facts in which the issues are to operate. It is to ensure against such a contingency that the Article uses the work 'may' and enables the Supreme Court to refuse to answer questions if it is satisfied that it should not express its opinion having regard to the questions and other relevant facts and circumstances.

The Court has emphasized that 'abstract' or speculative or hypothetical or too general questions should not be referred to it for advisory opinion. The Court has asserted that if a reference made to it is "vague and general" or if for any appropriate reason, the Court considers it "not proper or possible" to answer the reference, the Court may return it by pointing out the impediments in answering it. The Court has said that the plain duty and function of the Court is to consider the question on which the President has made the reference and report to the President its opinion. If for any reason, the Court considers it not proper or possible to answer the question, it would be entitled to return the reference by pointing out the impediments [5] However, in Art. 143 (2), the 
use of the word 'shall' indicates that the Supreme Court has to give its opinion on a reference made there under[6] There is a reason for his dichotomy between Arts. 143 (1) and 143 (2). Whereas it may be possible to agitate before the Courts the matters falling under Art. 143 (1) by adopting suitable procedures and techniques, the matters referred to in Art. 143 (2) are banned from judicial scrutiny of the Supreme Court, High Court or any other Court because of the operations of Arts. 131 and 363 and there is no other way to get a judicial verdict on these matters, if it ever becomes necessary, except through the machinery of Art. 143 (2). Hence the Supreme Court is constitutionally obligated to give its opinion if ever it is sought on the type of questions referred to in Art. 143 (2).

\section{CRITICISM OF CONSULTATIVE JURISDICTION}

The utility and propriety of the Institution of advisory jurisdiction is debatable. Though the Institution is not without its advantages, it has also attracted severe criticism. The whole notion of consultation of the judiciary is, by hypothesis a contradiction. The judges do not sit in the seat of justice in order to be consulted but in order to decide an issue. Arguments against the provision of advisory jurisdiction can briefly be put as under -

Firstly, criticism relates to the nature of advisory opinions. The opinions, technically, are merely advisory in nature. They bind neither the President nor the judges. An opinion given under the exercise of Article 143 is not 'law' within the meaning of Article 141 hence is not binding on lower courts[7]. Accepted theory of precedent tells that judges do not make law, only by formulation and declaration, they make law by applying it. Judicial declaration unaccompanied by judicial application is of no authority. In case of an advisory opinion, the court declares law but has no occasion to apply the same to a dispute between parties. The very fact that the subject of advisory opinions finds place in an article later than 141 is in itself an indication that an advisory opinion would be no more than opinion.

Secondly, the advisory opinions are criticized on the grounds that they are speculative and based on hypothetical, abstract and academic considerations. Justice Frankfurter took an opinion, given on the validity of prepared bills as void of any intrinsic value because of the psychologically unreal atmosphere in which the opinion moves on account of the questions being sterilized and mitigated for want of the impact of actuality and intensities of immediacy [8]. A constitutional commentator [9] has pointed out that the expression of such opinion on any issue or issues that may be referred to it means a kind of pre-commitment on the part of the court to a certain point of view and this may create a difficult and embarrassing situation later on when a concrete case involving more or less similar issue comes before it for adjudication. Hence, the litigant concerned may not quite feel confidence in the impartiality of the Court in such circumstances.

Thirdly, the critics are afraid of the provision under Article 143 being abused by the executive for political purposes. The executive may refer to the court questions involving political issues. Consequently, judiciary would be drawn into political controversies with the danger of loss of popular respect, impartial image and abandonment of truly judicial standards. There are instances where Presidential references arose much political controversies.-The Kerala education bill reference raised questions on which the public opinion in Kerala was greatly agitated. Berubari reference involved political issues. Similar situation arises in Ayodhya reference. The Court was asked to give opinion on whether a temple originally existed at the site, where the Babri Masjid subsequently stood. In the Presidential reference on Gujarat issue, segment of political parties said that ruling party is misusing the power of advisory jurisdiction. Thus, through such references by seeking advice from the Supreme Court the executive is able to drag judiciary into political controversies.

Fourthly, it is pointed out that the Court in tendering advisory opinions does not hear arguments from contesting parties but only dwells upon suggestions from the Union, the States and interveners which are allowed to by the Court. That is why, it is seen that there are less dissents in opinions that in normal judicial decisions [10]. Arguments in advisory proceedings move in unreal atmosphere and possible situations which would arise are imagined.

Lastly, advising executive by judiciary, it is argued, violates the principles of separation of powers. Advisory function is not a judicial one. To advise executive or legislature is an executive function. The U.S. Supreme Court has consistently declined to exercise any powers other than those which are strictly judicial in their nature. It is also argued that the Order of reference to the highest judiciary amounts to a gesture of command or a threat which undermine the dignity and independence of judiciary.

\section{ASSAY OF CRITICISM}

To understand the provision fully and correctly, every point of criticism has to be assessed categorically. First, about the non-binding nature of the opinions, it is true that technically the opinions are merely advisory, for they are not the results of judicial adjudication properly so called. But in practice, they are treated as having the same efficacy, authority and value as the judgments of the Supreme Court. Chief Justice, Gawyer of the Federal Court ruled that advisory opinions are not to be treated any the less binding on account 
of being advisory. Lower courts treat an advisory opinion to be as authoritative as a judgment in a case coming before the court in the normal manner. The referring authority, the President or practically the Union Government on the other hand, has always honored and obeyed the opinions given even in case when an opinion of the Supreme Court went against the wishes of the Union Government, i.e. the Berubari case, it was obeyed up to the fullest extent. The opinion in the Keshav Singh case [11] largely favored the High Court in Allahabad as against the Uttar Pradesh Legislative Assembly and in spite of the express dissatisfaction of the Assembly, all parties respected the opinion. The opinions practically do possess judicial character.

Secondly, the phrase 'likely to arise'[12] used in Clause of Article 143 provides room for reference to the court issues of doubtful maturity and hence attracts the criticism that advisory opinions are based on speculative, hypothetical, abstract and academic considerations. This is a real danger. But the experience with the institution so far does not present a serious threat at present. The problem of abstractness in the extreme form of the levy case [13] has not recurred. Besides, the Court in such cases, has the option to decline the reference. In the Presidential Poll reference case the court came across a hypothesis; what would be the situation if there was a malafide dissolution of a State Assembly or Assemblies or a malafide refusal to hold elections? The Court rightly refused to lend any consideration to the question at that stage.

Thirdly, by the institution of advisory jurisdiction, it is feared the President acting on instructions of the political head of the Government, can use the impartial judiciary for political ends or it may result in judicial intrusion in political affairs. This fear can be diluted in both the referring and answering authorities restrain themselves to act within the limits. The institution is not faulty; the need is that the persons who run the institution behave properly. The executive should hesitate in referring political questions for judicial advice and then the court should be careful not to entertain such references. Of course, the requirement of clause (1) of Article 143 that a question be of 'public importance' suggests that some political heat may be tolerable in the interest of judicial settlement of an otherwise unmanageable dispute.

Fourthly, it is pointed out that there are no contesting parties in a reference case and hence proceedings in reference cases lack legal representation. It is, however, a theoretical structure. Practically, the Court follows almost the same procedure in advisory proceedings as is followed in contested cases. The parties likely to be affected generally are given notice and are allowed to be represented in Court through their advocates. In some cases amicus curiae also are called to present the view point of unrepresented parties. A constitution commentator [14] believes that absence of briefs and oral arguments encourages the court to frame the constitutional matters more precisely, reduces the time taken to reach a decision and results in short opinions.

Finally, no ground is left for such a argument that judicial consultation by the executive violates the principle of separation of powers once it is settled that advisory function of judiciary does have a judicial character, no ground is left for such argument. Even if, for arguments' sake it be accepted that the principle of separation of powers is affected by the advisory opinions, we should keep in mind that the principle is designed to serve governmental efficiency and not the vice versa. Besides, existence of a large number of Tribunals has already violated this theory and, therefore, the argument looses any weight. It is argued, further that requiring judiciary to advise executive results in loss of prestige and independence of the former. In answer to it, the singular instance of the judicial committee of the Privy Council which is an advisory body to the crown acting on judicial lines can be called to mind. On the other hand, it assists in the governance of the country by giving advice to the executive and legislature to act in accordance with the constitution.

\section{ADVANTAGES OF CONSULTATIVE JURISDICTION}

Advisory function of judiciary has a number of advantages to its credit.

1) It accelerates the process of judicial review and hence saves time and energy both.

2) Taking advice beforehand leads to a prompt removal of doubts in the mind of the public or the Government

3) It creates possibilities of judicial review where the Constitution has barred any judicial interference i.e. proviso to Article 131.

4) The constitution presents some situations where legal rights exist but no legal remedies are available. In at least six situations the Constitution has created legal rights for which there is no legal remedy i.e.- article 31 (2), 359 (1), 329, 109 (3), 199 (3) and 363. The institution of advisory jurisdiction can help in such situations. (5)To depends solely on a real controversy for deciding a constitutional issue means that the court's jurisdiction depends on the whims of private litigants, and vital questions of constitutional law may remain clouded and unanswered by the highest Court for long till a suitable case arises and reaches the Court.

5) The ordinary court procedure is time-consuming and expensive as the case must pass through several courts before reaching the highest court and for this period a cloud of uncertainty would hang around the law, and the ultimate decision may very much depend on how and when a question is raised. 


\section{SUGGESTIONS}

The institution of Consultative Jurisdiction established a channel between the executive and the Judiciary. Its importance as a constitutional pronouncement has been appreciated throughout the Anglo Saxon world. For better working of the system, certain modifications in the provision may be suggested to make it more useful and less harmful.

1. Article 143 authorizes only the President, practically the Union Government to refer any question whether or not a Union subject to the Supreme Court. This power injudiciously, may result to grave injustice to the rights of the sates and individual citizens. The President has sometimes made a reference not only regarding questions affecting the Union but also on questions affecting the states without their consent and even contrary to their wishes. President should be empowered to refer only issues which come within the Union Governments domain, or in regard to any issue involving state subjects or state rights, the President should make a reference only on the initiative of the State Government.

2. Article 143 (1) empowers the President in his discretion to refer questions of both Law and Fact. It should be kept in mind that the similar provision [15], in the old statute allowed only questions of law to be referred to the Court. The ad hoc committee on Supreme Court (1947) also recommended only questions of law for reference to the Court. It is understandable that what prompted the constituent Assembly to broaden the jurisdiction to include questions of fact also. The inspiration seems to come from the Canadian system [16], where Governor General can refer to the Supreme Court "Important questions of law or fact... touching any matter." It does not suit the Indian system.

The word fact may be meant to include anything and everything. Armed with such wide powers, the President may be tempted to make too frequent use of the advisory jurisdiction which may result in serious consequences. For instance, in Ram Janmabhoomi reference a question on fact was asked before the court, whether a Hindu temple existed in the area on which the structure stood. Court held that this question on fact was superfluous and unnecessary and opposed to secularism and favoured one religious community and, therefore, does not require to be answered. Again, in Jammu \& Kashmir resettlement Act in 2001 the Supreme Court declined to give any comments on it. In fact, it was a mistake on the part of Constitution framers to have a broadened the scope of advisory jurisdiction of the Court. So, only question of law, therefore, should be allowed for reference to the Court and the word fact should be deleted.

3. In clause (2) of Article 143 the word 'shall' must be deleted, as it makes it obligatory upon the Supreme Court to answer a reference. The judiciary should not be bound to deliver an opinion if it wishes not to do so but should be free to judge whether or not to entertain a reference. The practice upto now shows that no reference has been made under clause (2) and even then the Supreme Court has not declined even a single reference. Compelling the Court to pronounce an opinion would be gross interference with the judicial independence of the Supreme Court.

4. Court should not go too far in giving opinion. In the Special Courts Bill[17], the court went too far in answering the reference. In this case the whole Bill was referred to the Court for advice regarding its constitutional validity and no specific questions were formulated. The Chief Justice Y.B. Chandrachud observed that at one stage the court was 'seriously considering the proposal that it should return the reference 'unanswered'. The court was indeed asked to first find the 'technical lacunae' and then to help remove them. Yet the court accepted and answered the reference. In the Presidential Poll reference[18], the court was told that the reference did not include all and real questions on the issue. But the court refused to go beyond the recitals of the reference and decided to entertain it. This ready willingness of the court to answer a Presidential reference has been viewed with a caution.

5. Consultative jurisdiction should be invoked only sparingly and not frequently and only in such cases where factual situations are ripe, or where legal issues are capable of being formulated precisely and can be considered by the Court without much of a factual data and political questions should not be referred to the court for advice.

6. Opinions of Court on references must be delivered within stipulated time limit, otherwise they will be ineffective. In Gujarat Assembly election matter [19], the President referred questions on 19.8.2002 and the opinion was delivered on October 28, 2002. In between this, Narendra Modi continued as a Chief Minister of Gujarat after October 3, he became the first head of the Government in the country since independence to remain in power without facing the legislature for six consecutive months. His continuance in power may not be violative of any constitutional provision, but involves serious questions such as lack of propriety and non-accountability.

7. Advisory jurisdiction by the Supreme Court can be beneficial to the country only if the court continues to be free from any executive pressure. Issues in which the central government is keenly interested are likely 
to be referred to the Supreme Court for its advice. Opinion expressed by the court in such cases will receive public credibility if its judicial independence is beyond question.

\section{CONCLUSIONS}

Consultative jurisdiction of the Supreme Court of India as an institution is useful and should be continued. It is, in no way defective but problems arise only when the data-based and factual questions are sent for consultative jurisdiction. In such cases, it is often seen that the Supreme Court is not at ease. Therefore, the justification for its use must be carefully examined and weighed in the context of each case. The responsibility is of both the government as the questioner and the court in its capacity as guardian of the efficient working of the judicial system to see that its use does not become more of a danger to the long term interests of justice than a benefit. The institution of consultative or advisory jurisdiction is good if used judiciously and infrequently.

The President has sometimes made a reference not only regarding questions affecting the Union but also on questions affecting the states without their consent and even contrary to their wishes. In a federation, the states are not the subordinate units of the central government. It needs to be remembered that only the spirit of 'co-operative federalism' can preserve the balance between the union and the states to promote the good of the people and not an attitude of dominance or superiority. President should be empowered to refer only issues which come within the Union Governments domain, or in regard to any issue involving state subjects or state rights, the President should make a reference only on the initiative of the State Government. It is understandable that what prompted the constituent Assembly to broaden the jurisdiction to include questions of fact also. The inspiration seems to come from the Canadian system, where Governor General can refer to the Supreme Court for "Important questions of law or fact... touching any matter." It does not suit the Indian system.

The word 'fact' may be meant to include anything and everything. Armed with such wide powers, the President may be tempted to make too frequent use of the advisory jurisdiction which may result in serious consequences. Due to the adoption of Canadian Model of Consultative Jurisdiction under Article 143 in the Indian Constitution, the Supreme Court of India, in two instances of Ram Janmabhoomi reference and Jammu \& Kashmir resettlement Act in 2001 refused to answer the questions in Consultative Jurisdiction of Supreme Court of India.

\section{REFERENCES}

[1] Kagzi, Jain M.C., Constitution of India (India Law House, New Delhi, 2001)

[2] Jain, M.P., Indian Constituaional Law (Wadhwa and Company, Nagpur, 2002)

[3] Gujarat Assembly election matter (2002) 8 SCC-237

[4] In the matter of Cauvery Water Disputes Tribunal, AIR 1992 SC 522, 553, 554 : 1993 Supp.(1) SCC 96(2)

[5] In Re, the Special Courts Bill

[6] In re the Kerala Education Bill, 1957, AIR 1958 SC 956 also Keshav Singh's case AIR 1965 SC 745

[7] In re Allocation of Lands and Building AIR 1943 F.C. 13

[8] 37 Harvard Law Review (1924) at 1005-1008

[9] Banerjee, D.N., Some Aspects of the Indian Constitution(Prakash Bhavan,Calcutta,1970)

[10] Wagner, W.J., Advisory opinions in the Federal Judiciary, A comparative Study - A Comparative Study, 27 Kan. City L. Rev. (1958-59)

[11] A.I.R. 1965 S.C. 745

[12] In re Levy of Estate Duty certain questions regarding future Legislation on Levy Estate duty were referred to the Federal Court for opinion, but no draft Bill was submitted. Justice Zafrullah Khan, one of the judges hearing the reference, refused to give opinion because the reference was enveloped in thick fog of hypothesis and uncertainties and the opinion delivered on it could only rest 'upon a forest of assumptions' which must rob it of all value.

[13] In fact there is no instance of a reference of a question not yet in the stages of a draft bill again

[14] Field D.P. Advisory opinions - an analysis, Indiana Law Journal, 24(2), 1948-49, 220-21

[15] Section 213 of the Govt. of India Act, 1935

[16] Section 60 of the Canadian Supreme Court Act 1906

[17] A.I.R. 1979 SC 478

[18] A.I.R. 1974 SC 1682 : (1974) 2 SCC 33

[19] (2002) 8 SCC 237: (2002) 8 LT 389 